\title{
Results of a Preceptor Improvement Project
}

Darin Brink, MD; David Power, MD, MPH; Eric Leppink

BACKGROUND AND OBJECTIVES: The majority of medical students receive some of their training with a community preceptor. Nearly all of these preceptors are motivated by a desire to give back to their profession through teaching and they want to learn how to teach more effectively. Designing effective educational programs to improve preceptor teaching is important to upholding the quality of medical education.

METHODS: We designed an educational program consisting of readings, short videos, handouts and posters, as well as one-on-one sessions with a trained standardized medical student. The standardized student visited the community physician's office both before and after the preceptor engaged with the educational materials related to a subject area of the preceptor's choosing. We assessed the preceptor's teaching using three tools: self-evaluation, student reporting of observed behaviors, and an overall rating of teaching effectiveness.

RESULTS: Thirteen preceptors took part in this the educational intervention. Per the self-assessment, preceptors showed improved teaching competency for all items on the questionnaire, with 12 of the 21 items (57\%) showing statistically significant results $(P<.05)$. The standardized student reported that preceptors used more of eight desired teaching behaviors in the second mock preceptor encounter than they used in the first, with a mean increase of $1.46(P=.001)$. Overall teaching effectiveness scores increased, with a mean increase of $1.15(P=.001)$ on the 10-point scale. Moreover, all participants indicated they were either satisfied or highly satisfied with the program and that they would recommend this program to a colleague.

CONCLUSIONS: Our preceptor-improvement intervention led to demonstrable improvement in preceptor teaching, as measured by preceptor evaluation and evaluation by the standardized student. More research is needed to see if these results can be replicated and, in particular, to determine which aspects of the intervention were most useful.

(Fam Med. 2020;52(9):647-52.)

doi: 10.22454/FamMed.2020.675133

$\mathbf{M}$ ost US medical students receive some of their training in community settings, ${ }^{1-4}$ where they work with community preceptors who have had minimal formal training in teaching. ${ }^{5,6}$ Community preceptors-largely volunteer physicians-are keenly interested in improving their teaching effectiveness. ${ }^{5-7}$ Thus, improving preceptor teaching is an important goal. We developed a new preceptor improvement program and studied it to determine its effectiveness and acceptability for our community preceptors at the University of Minnesota.

\section{Methods}

To recruit potential participants for this project, we sent out 120 emails and postcards to all community physicians who had taken at least one University of Minnesota clerkship student in the last 2 years. Forty physicians expressed initial interest, of which 23 physicians enrolled in the project, and 13 physicians completed the project.

Interested preceptors completed an online form using Qualtrics software that included a self-assessment tool (pretest). The survey included questions about 21 teaching competencies across five domains (learner centeredness, interpersonal and communication skills, professionalism and role modeling, practicebased reflection and improvement, and learner evaluation) that the first author of this paper had previously validated and reported. ${ }^{8}$ The preceptors were asked to evaluate how often they demonstrated each competency along a 5-point scale (from never to always). After completing the survey, the physicians were asked to choose one of the five domains to work on during this selfimprovement project.

From the University of Minnesota, Department of Family Medicine and Community Health, Minneapolis, MN. 
A standardized medical student ${ }^{9}$ then contacted the preceptors about setting up an onsite visit. This was a second-year medical student who had been trained to portray an early third-year clerkship student on the first day in the clinic. The student gave a scripted oral presentation to the preceptor about a predetermined case, deliberately omitting some information. The student listened for questions, clarification, and feedback on the presentation from the preceptor. The student then noted the presence or absence of eight teaching behaviors (Table 1) ${ }^{10}$ and also gave the preceptor a global precepting score, ranging from 1 to 10 . These three markers-the student's global score, the number of observable behaviors, and the physician's selfassessment-represented the preintervention condition.

After establishing the baseline, the physicians were provided an overview of the project. Each physician was given one of five different posters (Figure 1) that summarized the skill that they had chosen to work on. The participants were next emailed a link to a website that housed the content about each of the five possible areas of improvement. For each domain, there was a short video that explained and provided demonstrations of the skills related to that domain. In addition, each preceptor was required to review a module on the 1-minute preceptor microskills. The participants were given a laminated card that summarized the 1-Minute Preceptor approach. After completing these items, the participants were provided a link to an online module with further content related to the domain that they had chosen.

The preceptors' progress on completing the online modules was verified through Qualtrics. After the preceptor completed the online content, the standardized student returned to the practice site and presented the same mock patient to the preceptor. Again, the preceptor was evaluated on the presence or absence of eight teaching behaviors and given an overall global score between 1 and 10. The preceptor again completed the self-assessment (posttest). The preceptor also evaluated the program's strengths and weaknesses and indicated their likelihood of recommending the course to other preceptors. The time commitment for this performance improvement project was, on average, 3 hours in total over the course of 4 weeks (range 2 weeks to 3 months).

The University of Minnesota Institutional Review Board deemed this study exempt (IRB ID: STUDY00003529).

\section{Results}

In the self-assessments, preceptors showed statistically significant improvement in 12 of the 21 teaching competencies (Table 2) on average. On average, one additional key teaching behavior was demonstrated during the precepting encounter after the intervention $(P=.001$, Table 3). On average, there was a 1.15-point improvement in the overall teaching effectiveness score $(P=.001$; Table 4$)$. In the exit survey, all participants indicated they were either satisfied or highly satisfied with the program, and all indicated that they would recommend this program to a colleague.

\section{Conclusions}

Preceptors of medical students want to improve as teachers. We implemented a mixed-modality performance improvement project that was well received by our preceptors. The time investment required for it was similar to that of other performance improvement projects. Participants not only reported feeling better prepared to teach medical students, but also demonstrated higher scores in a postintervention self-assessment. They also demonstrated more positive teaching behaviors and scored higher on a global teaching effectiveness scale after the intervention. Although the preceptors received content in only one of the five domains, there was significant improvement across the five domains regardless of which domain they had chosen. It may be that reviewing the list of competencies is itself didactic, as the preceptor was reminded of core desired teaching behaviors.

Table 1: Student Evaluation of Preceptor Teaching

\begin{tabular}{|l|l|}
\hline \multicolumn{1}{|c|}{ Domain } & \multicolumn{1}{c|}{ Item } \\
\hline Commit & Asked for my diagnosis, work-up, or therapeutic plan before their input. \\
\hline Probe & Asked me for the reasoning behind my decisions. \\
\hline General rules & Evaluated my knowledge of medical facts and my analytic skills. \\
\hline Feedback & Taught general rules or pearls that I can use in future patient care. \\
\hline Feedback & Gave me positive feedback on thinks I did correctly. \\
\hline Feedback & Explained why I was correct or incorrect. \\
\hline Learner-centered & Offered suggestions for improvement. \\
\hline Assessment & Asked me to self-evaluate. \\
\hline
\end{tabular}

Adapted from Furney SL, Orsini AN, Orsetti KE, Stern DT, Gruppen LD, Irby DM. Teaching the one-minute preceptor. A randomized controlled trial. J Gen Intern Med. 2001;16(9):620-624. doi:10.1046/j.1525-1497.2001.016009620.x 


\section{Priming for Efficient Patient Encounters}

Just like priming a pump, taking 1 minute to "PRIME" your learners prior to each patient encounter will improve efficiency and effectiveness of your teaching and patient encounters!

PRIMING INVOLVES 3 P's:

PREPARE with your learner at start of session; PRIME before each patient interaction; PLAN next steps.

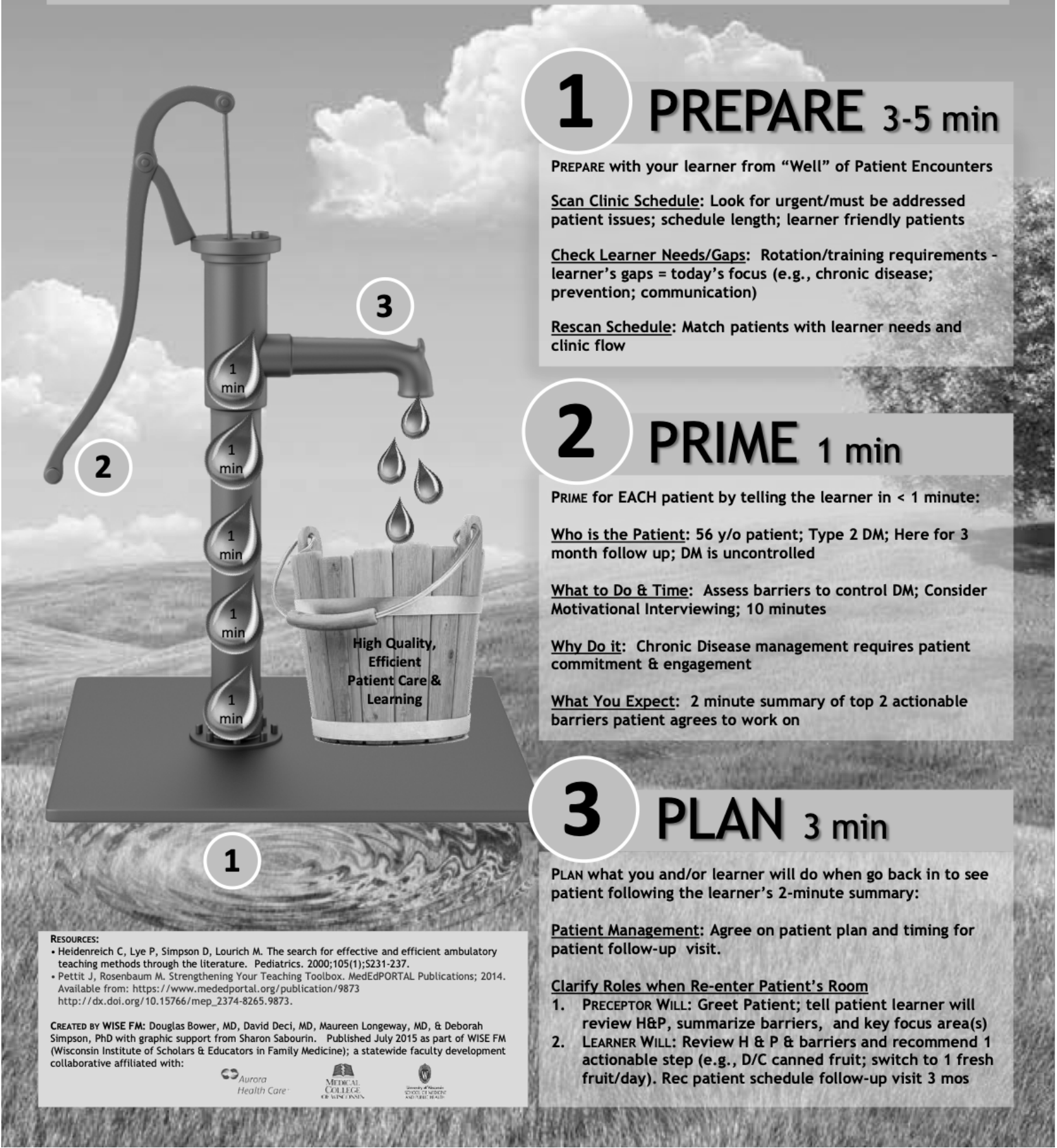

Used with permission from the Wisconsin Institute of Scholars and Educators in Family Medicine. 
Table 2: Change in Self-evaluation Scores

\begin{tabular}{|c|c|c|c|c|c|}
\hline \multirow[b]{2}{*}{$\begin{array}{l}\text { Domain: Patient and Learner Centeredness Goal } \\
\text { Goal: Demonstrate a commitment to the learner's } \\
\text { success and well-being leading to the learners' } \\
\text { growth into their professional roles. }\end{array}$} & \multirow[b]{2}{*}{$\begin{array}{l}\text { Pretest } \\
\text { Mean (SE) }\end{array}$} & \multirow[b]{2}{*}{$\begin{array}{l}\text { Posttest } \\
\text { Mean (SE) }\end{array}$} & \multicolumn{3}{|c|}{ Change (Post-Pre), n=14** } \\
\hline & & & $\begin{array}{l}\text { Change } \\
\text { Mean (SE) }\end{array}$ & $\begin{array}{l}\text { Mode } \\
(\mathrm{n}, \%)\end{array}$ & $P$ Value* \\
\hline $\begin{array}{l}\text { 1. Prepare the clinical environment, including staff, } \\
\text { patients, and other colleagues. }\end{array}$ & $\begin{array}{l}3.50 \\
(0.17)\end{array}$ & $4.21(0.16)$ & $\begin{array}{c}0.71 \\
(0.19)\end{array}$ & $\begin{array}{l}0(6,42.9 \%) \dagger \\
1(6,42.9 \%)\end{array}$ & .003 \\
\hline $\begin{array}{l}\text { 2. Orient the learner to the community, to local resources, } \\
\text { and to the clinical environment. }\end{array}$ & $\begin{array}{l}3.21 \\
(0.16)\end{array}$ & $\begin{array}{c}4.07 \\
(0.20)\end{array}$ & $\begin{array}{l}0.86 \\
(0.21)\end{array}$ & $1(9,64.3 \%)$ & .001 \\
\hline $\begin{array}{l}\text { 3. Ascertain each learner's knowledge, skills, and } \\
\text { attitudes related to rotation expectations and link to your } \\
\text { patients/clinic population. }\end{array}$ & $\begin{array}{l}3.43 \\
(0.20)\end{array}$ & $\begin{array}{l}3.86 \\
(0.14)\end{array}$ & $\begin{array}{c}0.43 \\
(0.23)\end{array}$ & $0(8,57.1 \%)$ & .082 \\
\hline 4. Assess and respond to the learner's cultural context. & $\begin{array}{l}3.29 \\
(0.19)\end{array}$ & $\begin{array}{c}3.79 \\
(0.24)\end{array}$ & $\begin{array}{c}0.50 \\
(0.23)\end{array}$ & $0(7,50.0 \%)$ & .047 \\
\hline $\begin{array}{l}\text { 5. Help learners develop learning goals aligned with } \\
\text { patients' needs. }\end{array}$ & $\begin{array}{l}3.36 \\
(0.17)\end{array}$ & $\begin{array}{l}3.86 \\
(0.14)\end{array}$ & $\begin{array}{l}0.50 \\
(014)\end{array}$ & $\begin{array}{c}0(7 \\
50.0 \%)^{\dagger \dagger} \\
1(7,50.0 \%) \\
\end{array}$ & .003 \\
\hline \multicolumn{6}{|l|}{ Bimodal, median=1, $\pitchfork$ Bimodal, median=.5. } \\
\hline $\begin{array}{c}\text { Domain: Interpersonal and Communication Skills } \\
\text { Goal: Teach and communicate effectively. }\end{array}$ & $\begin{array}{l}\text { Pretest } \\
\text { Mean (SE) }\end{array}$ & $\begin{array}{l}\text { Posttest } \\
\text { Mean (SE) }\end{array}$ & $\begin{array}{l}\text { Change } \\
\text { Mean (SE) }\end{array}$ & $\begin{array}{l}\text { Mode } \\
(\mathrm{n}, \%)\end{array}$ & $P$ Value* \\
\hline 1. Clearly communicate expectations to the learner. & $\begin{array}{l}3.43 \\
(0.17)\end{array}$ & $\begin{array}{c}4.21 \\
(0.11)\end{array}$ & $0.79(0.19)$ & $1(7,50 \%)$ & .001 \\
\hline 2. Tailor precepting style to the needs of the learner. & $\begin{array}{l}3.43 \\
(0.14)\end{array}$ & $\begin{array}{c}4.21 \\
(0.16)\end{array}$ & $0.79(0.21)$ & $1(8,57.1 \%)$ & .003 \\
\hline $\begin{array}{l}\text { 3. Identify barriers to learning (e.g. housing, geography, } \\
\text { psychological, economic, family, etc). }\end{array}$ & $\begin{array}{l}3.50 \\
(0.25)\end{array}$ & $\begin{array}{l}3.43 \\
(0.23)\end{array}$ & $\begin{array}{l}-0.07 \\
(0.37)\end{array}$ & $0(6,42.9 \%)$ & .850 \\
\hline $\begin{array}{l}\text { 4. Maintain a safe learning environment for the student } \\
\text { (ie, approachable, supportive, encouraging, student can } \\
\text { admit limitations). }\end{array}$ & $\begin{array}{l}3.79 \\
(0.26)\end{array}$ & $\begin{array}{l}4.93 \\
(0.07)\end{array}$ & $1.14(0.28)$ & $2(8,57.1 \%)$ & .001 \\
\hline $\begin{array}{l}\text { Domain: Professionalism and Role Modeling } \\
\text { Goal: Demonstrate best educational and evidence-based } \\
\text { practices and role model those behaviors for learners. }\end{array}$ & $\begin{array}{l}\text { Pretest } \\
\text { Mean (SE) }\end{array}$ & $\begin{array}{l}\text { Posttest } \\
\text { Mean (SE) }\end{array}$ & $\begin{array}{l}\text { Change } \\
\text { Mean (SE) }\end{array}$ & $\begin{array}{l}\text { Mode } \\
(\mathrm{n}, \%)\end{array}$ & $P$ Value* \\
\hline 1. Display enthusiasm for teaching. & $\begin{array}{l}4.29 \\
(0.16)\end{array}$ & $\begin{array}{c}4.71 \\
(0.13)\end{array}$ & $0.43(0.14)$ & $0(8,57.1 \%)$ & .008 \\
\hline $\begin{array}{l}\text { 2. Respectfully respond to each learner's unique needs } \\
\text { and learning goals related to patient care. }\end{array}$ & $\begin{array}{c}3.93 \\
(0.13)\end{array}$ & $\begin{array}{c}4.21 \\
(0.16)\end{array}$ & $0.29(0.22)$ & $0(7,50.0 \%)$ & .218 \\
\hline 3. Be available and accessible to learners. & $\begin{array}{c}4.21 \\
(0.19)\end{array}$ & $\begin{array}{c}4.57 \\
(0.17)\end{array}$ & $0.36(0.17)$ & $\begin{array}{c}0(10 \\
71.4 \%)\end{array}$ & .055 \\
\hline $\begin{array}{l}\text { 4. Acknowledge when beliefs/attitudes are influencing the } \\
\text { teaching/learning environment. }\end{array}$ & $\begin{array}{c}3.57 \\
(0.14)\end{array}$ & $\begin{array}{c}4.14 \\
(0.14)\end{array}$ & $0.57(0.17)$ & $0(7,50.0 \%)$ & .006 \\
\hline 5. Model highest standards of the profession. & $\begin{array}{c}4.21 \\
(0.16)\end{array}$ & $\begin{array}{c}4.57 \\
(0.14)\end{array}$ & $0.36(0.17)$ & $\begin{array}{c}0(10 \\
71.4 \%)\end{array}$ & .055 \\
\hline $\begin{array}{l}\text { Domain: Practice-based Reflection and Improvement } \\
\text { Goal: Role model continuous self- } \\
\text { assessment and lifelong learning. }\end{array}$ & $\begin{array}{l}\text { Pretest } \\
\text { Mean (SE) }\end{array}$ & $\begin{array}{l}\text { Posttest } \\
\text { Mean (SE) }\end{array}$ & $\begin{array}{l}\text { Change } \\
\text { Mean (SE) }\end{array}$ & $\begin{array}{l}\text { Mode } \\
(\mathrm{n}, \%)\end{array}$ & $P$ Value* \\
\hline $\begin{array}{l}\text { 1. Model the appropriate use of evidence-based medicine } \\
\text { in clinical practice. }\end{array}$ & $\begin{array}{c}3.57 \\
(0.20)\end{array}$ & $\begin{array}{c}4.21 \\
(0.15)\end{array}$ & $0.64(0.23)$ & $1(6,42.9 \%)$ & .013 \\
\hline $\begin{array}{l}\text { 2. Seek feedback from the learner and rotation director; } \\
\text { identify and act on improvement goals. }\end{array}$ & $\begin{array}{c}3.43 \\
(0.23) \\
\end{array}$ & $\begin{array}{c}3.64 \\
(0.20) \\
\end{array}$ & $0.21(0.24)$ & $0(9,64.3 \%)$ & .385 \\
\hline $\begin{array}{l}\text { 3. Engage in continuous learning as a physician and } \\
\text { teacher with targeted teaching goals. }\end{array}$ & $\begin{array}{l}3.57 \\
(0.20)\end{array}$ & $\begin{array}{l}4.14 \\
(0.14)\end{array}$ & $0.57(0.27)$ & $1(6,42.9 \%)$ & .055 \\
\hline
\end{tabular}


Table 2: Continued

\begin{tabular}{|c|c|c|c|c|c|}
\hline $\begin{array}{c}\text { Domain: Learner Assessment } \\
\text { Goal: Provide appropriate feedback. }\end{array}$ & $\begin{array}{l}\text { Pretest } \\
\text { Mean (SE) }\end{array}$ & $\begin{array}{l}\text { Posttest } \\
\text { Mean (SE) }\end{array}$ & $\begin{array}{l}\text { Change } \\
\text { Mean (SE) }\end{array}$ & $\begin{array}{l}\text { Mode } \\
(\mathrm{n}, \%)\end{array}$ & $P$ Value* \\
\hline 1. Solicit student self-assessment. & $\begin{array}{c}3.36 \\
(0.25)\end{array}$ & $\begin{array}{c}4.00 \\
(0.00)\end{array}$ & $0.64(0.25)$ & $0(9,64.3 \%)$ & .022 \\
\hline $\begin{array}{l}\text { 2. Provide timely formative and actionable feedback to } \\
\text { the learner regarding their progress (e.g., learning goals; } \\
\text { rotation competencies; knowledge, skills, and attitudes). }\end{array}$ & $\begin{array}{l}3.07 \\
(0.36)\end{array}$ & $\begin{array}{l}4.29 \\
(0.19)\end{array}$ & $1.21(0.38)$ & $2(4,28.6 \%)$ & .007 \\
\hline $\begin{array}{l}\text { 3. Check that formative feedback was heard and } \\
\text { understood, and that the learner initiated a feasible } \\
\text { action plan. }\end{array}$ & $\begin{array}{l}3.07 \\
(0.25)\end{array}$ & $\begin{array}{l}3.86 \\
(0.18)\end{array}$ & $0.79(0.38)$ & $0(4,28.6 \%)$ & .059 \\
\hline $\begin{array}{l}\text { 4. Provide summative feedback to the learner and the } \\
\text { medical institution. }\end{array}$ & $\begin{array}{l}3.57 \\
(0.34)\end{array}$ & $\begin{array}{l}4.29 \\
(0.16)\end{array}$ & $0.71(0.38)$ & $0(5,35.7 \%)$ & .086 \\
\hline
\end{tabular}

* $P$ value for paired $t$ test.

** One participant completed the self-assessment, but was unable to finish the mock precepting event.

Table 3: Student Evaluation-Observed Behaviors

\begin{tabular}{|l|c|c|c|c|c|c|}
\hline & $\mathbf{N}$ & $\begin{array}{c}\text { Pretest } \\
\text { Mean (SE) }\end{array}$ & $\begin{array}{c}\text { Posttest } \\
\text { Mean (SE) }\end{array}$ & $\begin{array}{c}\text { Change } \\
\text { Mean (SE) }\end{array}$ & Mode (n, \%) & $\boldsymbol{P}$ Value* \\
\hline Behaviors (possible range 0-8) & 13 & $\begin{array}{c}5.00 \\
(0.48)\end{array}$ & $\begin{array}{c}6.46 \\
(0.27)\end{array}$ & $\begin{array}{c}1.46 \\
(0.35)\end{array}$ & $\begin{array}{c}2.00 \\
(30.8 \%)\end{array}$ & .001 \\
\hline
\end{tabular}

* $P$ value for paired $t$ test.

Table 4: Student Evaluation-Effectiveness Score

\begin{tabular}{|c|c|c|c|c|c|c|}
\hline & $\mathbf{N}$ & $\begin{array}{c}\text { Pretest } \\
\text { Mean (SE) }\end{array}$ & $\begin{array}{l}\text { Posttest } \\
\text { Mean (SE) }\end{array}$ & $\begin{array}{l}\text { Change } \\
\text { Mean (SE) }\end{array}$ & $\begin{array}{l}\text { Mode } \\
(n, \%)\end{array}$ & $P$ Value* \\
\hline Overall Scores (possible range 0-10) & 13 & $7.00(0.38)$ & $8.15(0.32)$ & $1.15(0.25)$ & $1(46.2 \%)$ & .001 \\
\hline
\end{tabular}

* $P$ value for paired $t$ test.

Nearly every participant listed the interaction with the standardized student as the most valuable aspect of the project. It is unclear whether the exposure to the list of competencies, the poster, the online module, the video, or the time with the student played the most important role; likely it was the reinforcement of a message delivered via multiple modalities.

Several aspects of this project may be of value to other institutions designing teaching improvement programs. We used a set of previously vetted competencies that are clear and observable. Clear goals make for clearer instruction. Our use of a student as evaluator and a standardized student evaluation form is easy to replicate.

This study does have methodological limitations. We had a small sample size. We had no control group; any number of external inputs that our preceptors received during the study period could have played a role in the improvement seen and measured. As these preceptors all opted in, there is a high likelihood of bias; those who want to be better teachers completed this intervention. Also, 10 of the preceptors who opted in did not complete the project. While we did email them to confirm that they had withdrawn from the project, we did not inquire why they had not finished. The follow-up evaluation occurred 2 weeks to 3 months after the intervention. A longer interval was desirable as we wanted to know how long these concepts and skills had stuck. However, as participants were able to complete the content at their own pace, some completed it shortly before the student's second visit was scheduled. Finally, shortterm improvement in medical student teaching does not imply lasting improvement.

Further (and larger) studies are needed both to replicate our results and to better understand which aspects of this program were key to its effectiveness. In addition, future research could be done to see if similar effectiveness could be achieved with predominantly online content. 
ACKNOWLEDGMENTS: The authors thank Deb Finstad, who provided the statistical analysis for this paper.

PREVIOUS PRESENTATIONS: A preliminary report of the findings from this performance improvement project was previously presented at the 2019 STFM Medical Student Education Conference, February 1-3, 2019, Jacksonville, FL.

CORRESPONDING AUTHOR: Address correspondence to Dr Darin Brink, Family Med/ Community Health, MMC 381 Mayo, 516 Delaware St SE, Minneapolis, MN 55455. 651-227-6551.dbrink@umn.edu.

\section{References}

1. Carney PA, Eliassen MS, Pipas CF, Genereaux SH, Nierenberg DW. Ambulatory care education: how do academic medical centers, affiliated residency teaching sites, and community-based practices compare? Acad Med. 2004;79(1):69-77.

2. Fields SA, Usatine R, Stearns JA, Toffler WL, Vinson DC. The use and compensation of community preceptors in U.S. medical schools. Acad Med. 1998;73(1):95-97.
3. Irby DM. Where have all the preceptors gone? Erosion of the volunteer clinical faculty. West J Med. 2001;174(4):246.

4. Zinsmeister CS, Siu AL. Clinical teaching by voluntary faculty. Acad Med. 1993;68(5):355356.

5. Lacroix TB. Meeting the need to train more doctors: the role of community-based preceptors. Paediatr Child Health. 2005;10(10):591594. 1

6. Roberts KB, DeWitt TG. Faculty development of pediatric practitioners: complexities in teaching clinical precepting. Pediatrics. 1996;97(3):389-393.

7. Erikson C, Hamann R, Levitan T, Stanley J, Whatley M. Recruiting and maintaining US clinical training sites: joint report of the 2013 multi-discipline clerkship/clinical training site survey. Washington, DC: Association of American Medical College; 2014. https://paeaonline. org/wp-content/uploads/2015/10/Recruitingand-Maintaining-U.S.-Clinical-Training-Sites. pdf. Accessed July 10, 2020

8. Brink D, Simpson D, Crouse B, Morzinski J, Bower D, Westra R. Teaching competencies for community preceptors. Fam Med. 2018;50(5):359-363.
9. Simpson DE, Lawrence SL, Krogull SR. Using standardized ambulatory teaching situations for faculty development. Teach Learn Med. 1992;4(1):58-61.

10. Furney SL, Orsini AN, Orsetti KE, Stern DT, Gruppen LD, Irby DM. Teaching the one-minute preceptor. A randomized controlled trial. J Gen Intern Med. 2001;16(9):620-624. 